\title{
Strategi Peningkatan Daya Saing Ikan Bandeng Olahan Di Kota Serang Banten
}

\section{Increasing the Competitiveness Strategy of Milkfish in Serang City, Banten Province}

\author{
Ahmad Ridloudin ${ }^{1 *}$, Sapta Raharja ${ }^{2}$, dan Suryahadi ${ }^{3}$ \\ 1* Program Magister Pengembangan Indusri Kecil Menengah, Sekolah Pascasarjana IPB \\ ${ }^{2}$ Departemen Teknologi Industri Pertanian, Fateta IPB \\ Jl. Kamper Kampus IPB Darmaga Bogor 16680 \\ ${ }^{3}$ Departemen Ilmu Nutrisi dan Teknologi Pakan, Fapet IPB \\ Jl. Agatis Kampus IPB Darmaga Bogor 16680
}

\begin{abstract}
ABSTRAK
Bandeng adalah ikan milik suku Chanidae yang tersebar di sebagian besar wilayah Indonesia. Metode yang digunakan dalam menentukan responden adalah metode purposive sampling. Berdasarkan hasil analisis SWOT, ada empat strategi yang diperoleh dalam meningkatkan daya saing bandeng olahan antara lain; (a) mengembangkan sistem dan bisnis agribisnis ikan bandeng yang berkelanjutan, (b) membangun sistem bisnis yang kompetitif, sinergis, saling menguntungkan dan teknologi yang berfokus pada efisiensi, (c) kelembagaan, kemitraan dan pengembangan terintegrasi UKM ikan olahan terpadu, dan (d) keterlibatan pemerintah dalam kebijakan dalam bentuk peraturan yang mendukung peningkatan UKM olahan bandeng di Kota Serang. Hasil analisis QSPM menemukan bahwa strategi alternatif yang menjadi prioritas utama untuk meningkatkan daya saing ikan bandeng olahan di Kota Serang adalah membangun sistem bisnis yang kompetitif, sinergi, saling menguntungkan, dan fokus teknologi untuk efisiensi.
\end{abstract}

Kata kunci: bandeng, peningkatan daya saing, strategi

\section{ABSTRACT}

Milkfish is a fish belonging to the Chanidae tribe which is spread throughout most parts of Indonesia. The method used in determining respondents is purposive sampling method. Based on the results of the SWOT analysis, there are four strategies were obtained in increasing the competitiveness of processed milkfish include; (a) developing a sustainable milkfish agribusiness system and business, (b) building a business system that is competitive, synergistic, mutually beneficial and technology focused on efficiency, (c) institutional, partnership and integrated development of integrated processed fish SMEs, and (d) government involvement in policies in the form of regulations which favor the improvement of milkfish processed SME s in Serang City. The result QSPM analysis found that the alternative strategy which becomes the main priority to increased competitiveness of processed milkfish in Serang City is building a competitive business system, synergy, mutual benefit and technology focus for eficiency.

Key words: increasing the competitiveness, milkfish, strategy

\section{PENDAHULUAN}

Kementerian Kelautan dan Perikanan (KKP) telah menetapkan tiga kebijakan pokok pembangunan kelautan dan perikanan sebagai kerangka mewujudkan Indonesia sebagai poros maritim dunia, meliputi (a) menerapkan prinsip-prinsip pengelolaan sumberdaya kelautan dan perikanan yang bertanggung jawab, berdaya saing, dan berkelanjutan, (b) membangun kedaulatan yang mampu menopang kemandirian ekonomi dalam pengelolaan

\footnotetext{
*) Korespondensi:

Perum Cilebut Residence, Cluster Bougenville, Cilebut Barat, Sukaraja, Bogor; email: arn.kkp@gmail.com
} 
sumberdaya kelautan dan perikanan, dan (c) meningkatkan pemberdayaan dan kemandirian dalam menjaga keberlanjutan usaha kelautan dan perikanan.

Langkah konkrit yang dapat dilakukan dalam meningkatkan daya saing sumberdaya kelautan dan perikanan melalui pengoptimalan potensi-potensi sumberdaya yang ada, seperti perikanan air tawar, air payau, dan air laut. Atas dasar potensi laut yang dimiliki Indonesia, memicu munculnya beberapa perusahan yang mengelola hasil laut. Ikan bandeng merupakan ikan air payau yang termasuk dalam suku Chanidae, dimana ikan yang muda dan baru menetas hidup di laut selama 2-3 minggu, kemudian berpindah ke rawa-rawa bakau berair payau atau danau-danau berair asin serta kembali ke laut setelah dewasa untuk kembali berkembang biak. Ikan bandeng mempunyai toleransi salinitas yang tinggi dan dapat dibudayakan pada tambak yang berarir payau.

Berdasarkan Penelitian Hafiludin (2015), bahwa ikan bandeng dari habitat yang berbeda mempunyai rendemen yang berbeda. Rendemen ikan bandeng air tawar 38,5\%, dan air payau $50,8 \%$. Ikan bandeng adalah ikan yang kaya akan sumber protein (20-24\%), lemak, asam amino, asam lemak, mineral dan vitamin dengan rendemen daging sekitar 12\% (air tawar) dan 50,8\% (air payau).

Kandungan gizi yang tinggi yang terdapat pada ikan bandeng, menjadi peluang dan potensi yang besar untuk dijadikan sebagai produk olahan ikan yang bernilai tambah. Nusantari, et al (2016), menyebutkan diversifikasi produk ikan bandeng adalah salah satu inovasi untuk membantu pengurangan krisis ekonomi masyarakat. Ikan bandeng tanpa duri memiliki peluang bisnis yang menguntungkan dilihat dari nilai tambahnya, sehingga meningkatkan pendapatan masyarakat pesisir.

Peningkatan pendapatan dan kesejahteraan masyarakat pesisir dan pelaku UKM olahan ikan bandeng dapat dilakukan melalui upaya meningkatkan daya saing olahan ikan bandeng sehingga mampu bersaing dengan produk olahan lainnya. Menurut Dhelia, et al. (2018), terdapat beberapa strategi yang dapat dikembangkan guna meningkatkan daya saing industri bandeng, yaitu peningkatan kualitas sumberdaya manusia, terciptanya kemudahan akses sumberdaya modal, penguatan infrastruktur, serta kemudahan kerjasama dengan industri pendukung dan industri terkait.
Menurut Porter (2001:12-14), pentingnya daya saing yaitu (1) mendorong produktivitas dan meningkatkan kemampuan mandiri, (2) meningkatkan kapasitas ekonomi, baik dalam konteks regional ekonomi maupun kuantitas pelaku ekonomi, (3) kepercayaan bahwa mekanisme pasar lebih menciptakan efisiensi.

Kelemahan pembudidaya ikan bandeng dalam menciptakan daya saing bandeng adalah sulitnya dalam mengakses modal. Hal ini menyebabkan kualitas dan mutu ikan bandeng yang dihasilkan tidak sesuai dengan permintaan pasar, terutama pasar global. Selain itu, akses terhadap teknologi pengolahan ikan bandeng sulit diperoleh petani sehingga nilai tambah menjadi rendah. Implikasi dari kondisi ini adalah kesejahteraan pembudidaya dan pelaku usaha ikan bandeng tidak sesuai dengan harapan karena harga ikan bandeng yang diterima lebih rendah.

Mutu ikan bandeng yang baik akan memberikan dampak yang postif dan manfaat yang baik bagi konsumen. Oleh karena itu, penelitian ini dilakukan untuk mengetahui strategi yang baik dalam menciptakan daya saing ikan bandeng olahan di wilayah yang menjadi sentra pengolahan ikan bandeng. Salah satu sentra olahan ikan bandeng yang dijadikan sebagai wilayah dalam studi kasus penelitian ini adalah kota Serang, Banten

\section{METODE PENELITIAN}

Penelitian ini dilaksanakan di Kota Serang, Banten. Kegiatan penelitian mulai dilaksakan pada bulan Mei-Agustus 2019. Data yang diperlukan dalam penelitian ini adalah data primer dan data sekunder. Penelitian ini dirancang sebagai penelitian deskriptif dengan metode survei dan wawancara. Jenis dan sumber data yang digunakan dalam penelitian ini adalah data primer dan data sekunder, baik kualitatif maupun kuantitatif. Data primer diperoleh melalui pengamatan (observasi) di lapangan, wawancara, dan pengisian kuesioner oleh responden terpilih.

Metode yang digunakan dalam penentuan responden adalah metode purposive sampling, yaitu dengan sengaja memilih pakar yang kompeten dan terlibat langsung dalam pengawasan/penerapan/pembinaan/penelitian ikan bandeng olahan pada IKM. Berdasarkan datadata yang terkumpul tersebut disusun suatu 
strategi berdasarkan SWOT dalam memfasilitasi peningkatan ikan bandeng olahan pada IKM Kota Serang.

Penelitian ini terdiri dari tahap identifikasi pakar, analisis SWOT, analisis QSPM dan perumusan strategi. Namun, untuk mengidentifikasi dan menentukan produk unggulan yang menjadi prioritas utama dalam kajian penelitian ini menggunakan metode perbandingan eksponensial. Metode Perbandingan Eksponensial (MPE) merupakan salah satu metode Decision Suport System (DSS) yang digunakan untuk menentukan urutan prioritas alternatif keputusan dengan kriteria jamak. Teknik digunakan untuk membantu individu pengambil keputusan untuk menggunakan rancang bangun model yang terdefinisi dengan baik pada tahapan proses, sehingga menghasilkan nilai alternatif yang perbedaannya lebih kontras.

Formulasi penghitungan MPE: Total Nilai $(\mathrm{TN} i)=\sum_{j=1}^{m}(R K i j)^{\mathrm{TKKj}}$

Keterangan:

$\mathrm{TNi}=$ Total nilai alternatif ke-i

Rkij = Derajat kepentingan relatif kriteria ke-j pada pilihan keputusan ke-i

$\mathrm{TKKj}=$ Derajat kepentingan kriteria keputusan ke-j TKKj>0; bulat

$\mathrm{n} \quad=$ jumlah pilihan keputusan

$\mathrm{m} \quad=$ jumlah kriteria keputusan

Menurut David (2009), untuk menganalisis lingkungan perusahaan baik lingkungan internal maupun lingkungan eksternal dapat dilakukan melalui tiga tahap, yaitu tahap input (input stage), tahap pencocokan (matching stage), dan tahap keputusan (decision stage). Model yang dipakai terdiri atas:

a. Matriks Evaluasi Faktor Eksternal (EFE)

b. Matriks Evaluasi Faktor Internal (IFE)

c. Matriks Internal Eksternal (IE)

d. Matriks SWOT

\section{HASIL DAN PEMBAHASAN}

\section{Analisis Identifikasi Penentuan Produk Olahan Ikan Potensial}

Penentuan produk ikan bandeng olahan sebagai produk unggulan dibandingkan dengan produk olahan lainnya dilakukan melalui kriteria-kriteria yang dituangkan dalam kuesioner. Terdapat empat jenis sumberdaya potensial yang akan dikembangkan sebagai produk olahan di kota Serang antara lain ikan bandeng, rumput laut, udang, dan ikan kerapu. Dalam penentuan ikan bandeng sebagai produk olahan dapat dilihat pada Tabel 1.

Tabel 1. Urutan Prioritas UKM Ikan Olahan Kota Serang

\begin{tabular}{clc}
\hline $\begin{array}{c}\text { Urutan } \\
\text { Prioritas }\end{array}$ & $\begin{array}{c}\text { Jenis Produk } \\
\text { Olahan Ikan UKM }\end{array}$ & $\begin{array}{c}\text { Total Nilai } \\
\text { MPE }\end{array}$ \\
\hline 1 & Ikan bandeng & 411.287 .168 \\
2 & Rumput laut & 202.568 .320 \\
3 & Udang & 172.833 .771 \\
4 & Ikan kerapu & 30.179 .168 \\
\hline
\end{tabular}

Berdasarkan Tabel 1, dari hasil analisis MPE dapat disimpulkan bahwa prioritas utama jenis produk olahan ikan untuk pengembangan UKM di kota Serang Banten adalah ikan bandeng. Nilai MPE untuk ikan bandeng sebesar 411.287.168, dan nilai ini lebih besar dibandingkan dengan jenis produk olahan ikan lainnya. Oleh karena itu, produk olahan ikan yang yang prioritas dan prospektif untuk dikembangkan oleh para pelaku UKM di kota Serang Banten adalah ikan Bandeng.

Pemilihan komoditas ikan bandeng olahan dipengaruhi oleh beberapa faktor antara lain kontinuitas bahan baku, nilai tambah produk, potensi pasar, ketersediaan SDM memadai, penyerapan tenaga kerja, teknologi yang sudah dipakai, dampak terhadap lingkungan, dan kondisi sosial budaya. Berdasarkan penelitian Dhelia et al (2018), menyebutkan bahwa faktor priotas yang menentukan peningkatan daya saing ikan bandneg olahan adalah sumber daya modal, dengan aktor dan tujuan utama adalah pelaku usaha dan meningkatkan pendapatan pelaku usaha.

\section{Analisis Matriks IFE}

Matriks IFE digunakan untuk menganalisis faktor internal berupa kekuatan dan kelemahan dalam peningkatan daya saing ikan bandeng olahan di kota Serang Banten. Hasil analisis matriks IFE dapat dilihat pada Tabel 2.

Berdasarkan Tabel 2, kekuatan utama dalam peningkatan daya saing olahan ikan bandeng di Kota Serang adalah Kreativitas Pelaku Usaha UKM yang Tinggi dalam menciptakan nilai tambah ikan bandeng dengan skor 0,1970. Kelemahan utama dalam peningkatan daya saing ikan bandeng olahan di kota Serang adalah kendala permodalan yang sering 
dihadapi oleh UKM kota Serang dengan skor 0,0956 . Total skor yang diperoleh pada matriks IFE berada diats skor 2,5, yaitu 2,6482, menunjukkan bahwa kondisi internal yang dimiliki UKM Kota Serang cukup kuat dan relatif mampu menggunakan kekuatan yang dimiliki dalam mengantisipasi kelemahan dalam meningkatkan daya saing ikan bandeng olahan.

\section{Analisis Matriks EFE}

Matriks EFE menjelaskan dua hal yang menjadi perhatian dalam peningkatan daya saing ikan bandeng olahan yaitu peluang dan ancaman. Skor yang diperoleh pada matriks EFE berada di atas 2,5, yaitu 2,6143, seperti pada Tabel 3.

Berdasarkan pada Tabel 3, menunjukkan peluang yang paling baik dalam meningkatkan daya saing ikan olahan bandeng di kota Serang karena trend pertumbuhan kunjungan penikmat kuliner ke kota Serang yang semakin meningkat. Nilai skor yang ditunjukkan pada peluang yang dimaksud tersebut sebesar 0,2514 . Selanjutnya, ancaman yang paling berat yang dihadapi dalam peningkatan daya saing ikan bandeng olahan di kota Serang adalah daya saing produk olahan ikan selain bandeng yang lebih kompetitif, dengan nilai skor sebesar 0,1235 .

\section{Matriks IE}

Hasil perhitungan pada analisis matriks IFE dan EFE diperoleh total nilai sebagai berikut 2,6482 (nilai IFE) dan 2,6143 (nilai EFE). Atas dasar teori dari Rangkuti (2014) dan David (2009), dapat dibuatkan model matriks IE untuk strategi peningkatan daya saing ikan bandeng olahan di Kota Serang, seperti pada Gambar 1.

Tabel 2. Hasil Analisis Matriks IFE Olahan Ikan Bandeng Kota Serang

\begin{tabular}{|c|c|c|c|}
\hline Faktor Penentu & $\begin{array}{l}\text { Bobot } \\
\text { (a) }\end{array}$ & $\begin{array}{l}\text { Rating } \\
\text { (b) }\end{array}$ & $\begin{array}{l}\text { Skor } \\
(\mathrm{axb})\end{array}$ \\
\hline \multicolumn{4}{|l|}{ Strengths } \\
\hline - Beragam UKM olahan Ikan Bandeng di Kota Serang & 0,0455 & 4 & 0,1821 \\
\hline - Sosial Budaya Masyarakat Mendukung untuk Bisnis Olahan Ikan Bandeng & 0,0478 & 4 & 0,1914 \\
\hline $\begin{array}{l}\text { - Kreativitas Pelaku Usaha UKM yang Tinggi dalam menciptakan nilai } \\
\text { tambah ikan bandeng }\end{array}$ & 0,0492 & 4 & 0,1970 \\
\hline - Tingginya kesadaran masyarakat terhadap bisnis olahan ikan bandeng & 0,0493 & 3 & 0,1481 \\
\hline - Trend pertumbuhan UKM bidang olahan ikan bandeng yang positif & 0,0458 & 4 & 0,1833 \\
\hline $\begin{array}{l}\text { - Daya tarik konsumen terhadap olahan ikan bandeng di Kota Serang yang } \\
\text { tinggi }\end{array}$ & 0,0434 & 4 & 0,1739 \\
\hline - Potensi Ikan Bandeng di Wilayah Serang Banten sangat Baik & 0,0471 & 3 & 0,1414 \\
\hline $\begin{array}{l}\text { - Ketersedian Suplay Ikan Bandeng di Kota Serang Fresh, dan Jumlah } \\
\text { Memadai }\end{array}$ & 0,0481 & 3 & 0,1443 \\
\hline $\begin{array}{l}\text { - Kemudahan UKM olahan ikan bandeng dalam promosi melalui media } \\
\text { cetak, maupun online }\end{array}$ & 0,0477 & 3 & 0,1431 \\
\hline - Harga Bahan Baku yang terjangkau & 0,0498 & 3 & 0,1495 \\
\hline - Inovasi UKM ikan bandeng olahan diterima masyarakat luas & 0,0467 & 3 & 0,1401 \\
\hline - UKM kota Serang Menyerap Tenaga Kerja Cukup Tinggi & 0,0453 & 3 & 0,1360 \\
\hline \multicolumn{4}{|l|}{ Weaknesses } \\
\hline $\begin{array}{l}\text { - Kelembagaan yang kurang kuat di kalangan UKM olahan ikan bandeng di } \\
\text { Kota Serang }\end{array}$ & 0,0474 & 2 & 0,0948 \\
\hline - Rendahnya tingkat pendidikan SDM pelaku UKM di Kota Serang & 0,0492 & 2 & 0,0985 \\
\hline - Pembudidaya ikan bandeng sering menghadapi gagal panen & 0,0453 & 1 & 0,0453 \\
\hline - Teknologi olahan ikan bandeng masih sederhana & 0,0469 & 2 & 0,0939 \\
\hline - Kendala Permodalan sering dihadapi para UKM Kota Serang & 0,0478 & 2 & 0,0956 \\
\hline $\begin{array}{l}\text { - Kurangnya ruang terbuka hijau di Kota Serang sebagai daya tarik } \\
\text { pengunjung ke kota Serang }\end{array}$ & 0,0534 & 1 & 0,0534 \\
\hline - Belum meratanya implementasi SOP UKM yang baik & 0,0474 & 2 & 0,0949 \\
\hline - Pengemasan atau packing Olahan Ikan Bandeng masih rendah & 0,0512 & 1 & 0,0512 \\
\hline - Kesulitan memperoleh lokasi usaha yang strategis & 0,0446 & 2 & 0,0892 \\
\hline
\end{tabular}


Tabel 3. Hasil Analisis Matriks EFE Olahan Ikan Bandeng Kota Serang

\begin{tabular}{|c|c|c|c|}
\hline Faktor Penentu & $\begin{array}{l}\text { Bobot } \\
\text { (a) }\end{array}$ & $\begin{array}{l}\text { Rating } \\
\text { (b) }\end{array}$ & $\begin{array}{l}\text { Skor } \\
(\mathbf{a x b})\end{array}$ \\
\hline \multicolumn{4}{|l|}{ Opportunities } \\
\hline $\begin{array}{l}\text { - Trend pertumbuhan kunjungan penikmat kuliner semakin } \\
\text { meningkat }\end{array}$ & 0,0628 & 4 & 0,2514 \\
\hline $\begin{array}{l}\text { - Adanya dukungan pemerintah berupa regulasi terhadap } \\
\text { pertumbuhan UKM olahan ikan bandeng di Kota Serang }\end{array}$ & 0,0573 & 3 & 0,1720 \\
\hline $\begin{array}{l}\text { - Meningkatnya kesadaran masyarakat dalam mengkonsumsi ikan } \\
\text { bagi kalangan balita, anak anak maupun dewasa }\end{array}$ & 0,0569 & 3 & 0,1709 \\
\hline - SDM produktif di Kota Serang masih cukup tersedia & 0,0584 & 3 & 0,1753 \\
\hline - Inovasi budidaya ikan bandeng yang ramah lingkungan & 0,0558 & 4 & 0,2235 \\
\hline $\begin{array}{l}\text { - Komitmen para pelaku UKM olahan ikan bandeng dalam menjaga } \\
\text { Hiegienitas }\end{array}$ & 0,0569 & 3 & 0,1709 \\
\hline $\begin{array}{l}\text { - Tingginya minat masyarakat dalam mengkonsumsi olahan ikan } \\
\text { bandeng }\end{array}$ & 0,0558 & 4 & 0,2235 \\
\hline $\begin{array}{l}\text { - Tingginya Nutrisi dan Nilai Gizi Ikan Bandeng sangat baik } \\
\text { dikonsumsi untuk anak-anak }\end{array}$ & 0,0518 & 4 & 0,2073 \\
\hline $\begin{array}{l}\text { - Kemudahan akses Teknologi dan Informasi menjadi daya dukung } \\
\text { dalam peningkatan daya saing UKM olahan ikan bandeng }\end{array}$ & 0,0588 & 3 & 0,1764 \\
\hline $\begin{array}{l}\text { - Masih melekatnya budaya masyarkat untuk membeli oleh-oleh khas } \\
\text { daerah ketika mengunjungi suatu tempat }\end{array}$ & 0,0591 & 4 & 0,2367 \\
\hline \multicolumn{4}{|l|}{ Threats } \\
\hline - Anomali Iklim Usaha Budidaya dan Olahan Ikan kurang Kondusif & 0,0588 & 2 & 0,1176 \\
\hline - Persaingan dari industri olahan ikan & 0,0665 & 1 & 0,0665 \\
\hline $\begin{array}{l}\text { - Daya saing produk olahan ikan selain bandeng yang lebih } \\
\text { kompetitif }\end{array}$ & 0,0617 & 2 & 0,1235 \\
\hline $\begin{array}{l}\text { - Masih adanya mindset masyarakat terkait bau amis pada ikan } \\
\text { bandeng }\end{array}$ & 0,0573 & 1 & 0,0573 \\
\hline $\begin{array}{l}\text { - Pertumbuhan Industri yang menimbulkan pencemaran lingkungan } \\
\text { lokasi budidaya ikan Bandeng }\end{array}$ & 0,0625 & 1 & 0,0625 \\
\hline $\begin{array}{l}\text { - Tumpang Tindih penguasaan lahan produksi ikan antara petani atau } \\
\text { pelaku UKM dengan swasta }\end{array}$ & 0,0591 & 1 & 0,0591 \\
\hline - Tingkat Inflasi yang Fluktuatif & 0,0595 & 2 & 0,1191 \\
\hline Total & & & 2,6143 \\
\hline
\end{tabular}

\section{SKOR IFE}

Kuat 3,0-4,0 Sedang 2,0-3,0 Lemah1,0-2,0

Tinggi $(3,00-4,00)$

SKOR EFE Sedang $(2,00-2,99)$

Rendah (1,00-1,99)

\begin{tabular}{|r|c|c|c|}
\hline \multicolumn{1}{|c|}{$I$} & & II & III \\
\hline & $\begin{array}{c}\text { IFE } \\
\text { EFE }\end{array}$ & $(2,6482)$ & \\
\hline $\mathrm{IV}$ & \multicolumn{2}{|c|}{$\mathrm{V}$} & $\mathrm{VI}$ \\
\hline $\mathrm{VII}$ & & $\mathrm{IX}$ & $\mathrm{X}$ \\
\hline
\end{tabular}

Gambar 1. Model Matriks IE UKM Ikan Bandeng Olahan 
Berdasarkan hasil analisis pada matriks IE pada Gambar 1, jika dikaitkan dengan teori strategi dari Rangkuti (2014) diperoleh strategi peningkatan daya saing ikan olahan bandeng di kota Serang berada pada Sel V, yaitu strategi pertumbuhan (Growth Strategi), dan demikian halnya dengan teori David (2009) bahwa pada sel $\mathrm{V}$ menunjukkan strategi mempertahankan dan memelihara. Strategi mempertahankan dan memelihara digunakan untuk kondisi market penetration dan product development.

Berkaitan dengan upaya market penetration dan product development peningkatan daya saing ikan olahan bandeng di kota Serang, terdapat beberapa formulasi strategi alternatif yang dapat diperoleh melalui analisis dari kekuatan, kelemahan, peluang dan ancaman. Analisis ini dituangkan dalam bentuk matriks SWOT peniungkatan dsaya saing ikan bandeng olahan yang menjadi lanjutan dari analisis IE.

\section{Matriks SWOT}

Berdasarkan hasil analisis SWOT diperoleh empat strategi dalam peningkatan daya saing ikan bandeng olahan sebagai berikut:

\section{a. Strategi SO}

Strategi SO dalam peningkatan daya saing ikan bandeng olahan adalah mengembangkan Sistem dan Usaha Agribisnis Ikan Bandeng yang Berkelanjutan

b. Strategi ST

Strategi ST dalam peningkatan daya saing ikan bandeng olahan adalah membangun Sistem Usaha yang kompetitif, Sinergi, Saling Menguntungkan dan Fokus Teknologi untuk Efisiensi c. Strategi WO

Strategi WO dalam peningkatan daya saing ikan bandeng olahan adalah pengembangan Kelembagaan, Kemitraan dan Pengelolaan UKM Olahan Ikan yang Terintegrasi

d. Strategi WT

Strategi WT dalam peningkatan daya saing ikan bandeng olahan adalah melalui keterlibatan Pemerintah dalam kebijakan berupa regulasi yang berpihak kepada peningkatan daya saing UKM Olahan Ikan Bandeng di Kota Serang

Menurut penelitian Dhelia et al. (2018), bahwa strategi alternatif berdasarkan prioritas secara berturut-turut adalah strategi meningkatkan produksi, strategi penguatan infrastruktur, strategi peningkatan kerja sama antar stakeholder, strategi penyuluhan, serta strategi perbaikan regulasi.

\section{Analisis Matriks QSPM}

Hasil pembobotan QSPM yang dilakukan oleh lima responden, secara lebih ringkas hasil analisis QSPM dapat dilihat pada Tabel 4. Berdasarkan Tabel 4, diperoleh strategi yang paling prioritas dalam peningkatan daya saing ikan bandeng olahan di kota Serang adalah membangun sistem usaha yang kompetitif, sinergi, saling menguntungkan dan fokus teknologi untuk efisiensi. Menurut Mangkuprawira (2007), dua prinsip pokok yang perlu dimiliki perusahaan untuk meraih keunggulan kompetitif yaitu adanya nilai pandang pelanggan dan keunikan produk. Demikian halnya yang disampaikan Sunarsih (2017), bahwa kunci keberhasilan untuk mampu bertahan di tengah persaingan terletak pada kemampuan perusahaan dalam mem-bangun keunggulan kompetitifnya.

Tabel 4. Hasil analisis QSPM UKM Ikan Bandeng olahan Kota Serang

\begin{tabular}{|c|c|c|}
\hline Strategi Prioritas & Total Nilai TAS & Peringkat \\
\hline $\begin{array}{l}\text { - Mengembangkan Sistem dan Usaha Agribisnis Ikan Bandeng yang } \\
\text { Berkelanjutan }\end{array}$ & 4,9808 & 4 \\
\hline $\begin{array}{l}\text { - Membangun Sistem Usaha yang kompetitif, Sinergi, Saling } \\
\text { Menguntungkan dan Fokus Teknologi untuk Efisiensi }\end{array}$ & 6,2643 & 1 \\
\hline $\begin{array}{l}\text { - Pengembangan Kelembagaan, Kemitraan dan Pengelolaan UKM } \\
\text { Olahan Ikan yang Terintegrasi }\end{array}$ & 5,5507 & 3 \\
\hline $\begin{array}{l}\text { - Keterlibatan Pemerintah dalam kebijakan berupa regulasi yang } \\
\text { berpihak kepada peningkatan daya saing UKM Olahan Ikan } \\
\text { Bandeng di Kota Serang }\end{array}$ & 6,1095 & 2 \\
\hline
\end{tabular}




\section{KESIMPULAN}

a. Berdasarkan hasil analisis MPE, bahwa produk olahan ikan yang paling potensial untuk dikembangkan di Kota Serang Banten adalah ikan bandeng olahan. Hal ini ditunjukkan dengan nilai MPE untuk ikan bandeng olahan sebesar 411.287.168, dan nilai ini paling besar dibandingkan dengan jenis produk olahan ikan lainnya.

b. Faktor-faktor yang mempengaruhi peningkatan daya saing ikan bandeng olahan di kota Serang meliputi kontinuitas dari ketersediaan bahan baku, nilai tambah produk ikan bandeng yang beragam, potensi pasar ikan bandeng yang terbuka luas, memadainya SDM UKM ikan bandeng, tingginya penyerapan tenaga kerja dari UKM ikan bandeng olahan, dukungan teknologi dalam menciptakan efisiensi, ramah lingkungan dan dukungan sosial budaya masyarakat yang ada di Kota Serang.

c. Strategi peningkatan daya saing ikan bandeng olahan di Kota Serang Banten adalah melalui strategi mempertahankan dan memelihara (Growth Strategy), seperti yang ditunjukkkan pada hasil analisis matriks IE berada pada sel V. Namun, strategi yang paling prioritas dalam peningkatan daya saing ikan bandeng olahan di kota Serang adalah membangun sistem usaha yang kompetitif, sinergi, saling menguntungkan dan fokus teknologi untuk efisiensi dan inovasi kewirausahaan melalui inovasi produk untuk membangun keunggulan kompetitif antara lain dengan keunggulan produk, keunikan produk, dan biaya produk. Hasil analisis prioritas ini diperoleh berdasarkan analisis QSPM.

\section{DAFTAR PUSTAKA}

David, F.R. 2009. Konsep Manajemen Strategis. Jakarta: Salemba Empat.

Deli, R.O., S. Widjaya, dan T. Endaryanto. 2018. Analisis Strategi Pemasaran Berbagai Ikan Bandeng di Provinsi Lampung. JIIA, Volume 6, No. 2, Mei 2018.

Dhelia, I.A., R. Oktaviani, dan B.H. Iskandar. 2018. Strategi Peningkatan Daya Saing Industri Bandeng di Kabupaten Indramayu. Jurnal Ekonomi dan Kebijakan Publik, E-ISSN: 2528-4673, P-ISSN :20866313, Vol.09, No.1 juni 2018, hal 1-14.

Hafiludin. 2015. Analisis Kandungan Gizi pada Ikan Bandeng yang Berasal dari Habitat yang Berbeda. Jurnal Kelautan, Volume 8, No. 1, April 2015. ISSN :1907-9931.

Mangkuprawira, S. \& A.V. Hubeis. 2007. Manajemen Mutu Sumber Daya Manusia. Bogor: Penerbit Ghalia Indonesia.

Nusantari, E., A.Abdul., dan R.M. Harmain. 2016. Ikan Bandeng Tanpa Duri (Chanos chanos) sebagai peluang Bisnis Masyarakat Desa Mootinelo, Kabupaten Gorontalo Utara, Provinsi Gorontalo. Jurnal Agro Kreatif. Mei 2016, 3(1): 78-87, ISSN: 2460-8572, EISSN 2461-095X.

Porter, M.E. 1990. Competitive Advantage of Nations. New York: World Pres.

Sugito, A. Prahutama, dan A. Hoyyi. 2019. Diversifikasi Olahan Ikan Bandeng oleh UKM Primadona dalam Program Pengabdian IbPE 2016-2018. Jurnal Pengabdian Masyarakat Volume 10, Nomor 01, Maret 2019.

Sunarsih, N. 2017. Kewirausahaan dalam Multiperspektif: Membangun Keunggulan Kompetitif Melalui Inovasi dan Kewirausahaan. Universitas Terbuka, Tangerang Selatan. Penerbit Universitas Terbuka. ISBN 978602-392-156-0. 